\title{
EFFICACY OF FIBRIN MATRIX WITH NEUROINDUCED MESENCHYMAL STEM CELLS TRANSPLANTATION FOR RESTORATION SCIATIC NERVE FUNCTION AFTER ITS COMPLETE RUPTURE IN RATS
}

\author{
Piatykop V., Kaliuzhka V., Shchegelska O., Markevych M. \\ Kharkiv National Medical University, Ukraine \\ https://doi.org/10.35339/ic.6.3.168-173
}

\begin{abstract}
Peripheral nerves damage is a frequent pathology with significant socio-economic significance. The aim is to study the possibility of using fibrin matrices filled with neuroinduced mesenchymal stem cells (nMSC) to restore integrity of peripheral nerves. Methods. The study was carried out on 40 mongrel female rats. Sciatic nerves (SN) of all rats were intersected and then reconstituted using various methods. nMSC were obtained from rats` bone marrow and cultivated by special method. Results. Total anatomical rupture of SN without treatment led to persistent neurologic deficit $(\mathrm{SFI}=-98)$ in E1 group. Partial restoration of SN function increased to SFI $=-37$ on the $30^{\text {th }}$ day in E2 (operative reconstruction) group. Partial restoration of SN function occurred after 20 days (SFI = -64) in E3 group (transplanted acellular fibrin matrix). Partial restoration of SN function started at the $3^{\text {rd }}$ day, stably increased to SFI $=-27$ on $30^{\text {th }}$ day in E4 group (transplanted fibrin matrix with nMSC). Histological evaluation showed: there were alternating portions of connective tissue with portions of nerve fibers in E2 group; in E3 group large scar was formed at the place of transplanted fibrin matrix; in E4 were found spindle-shaped and stellate cells with long processes running from one side of SN to another, cells of connective tissue and thin nerve fibers. Conclusions. It has been shown that transplantation of the fibrin matrix with nMSC was more effective for treatment of SN trauma than transplantation of cell-free fibrin matrix and close to the results of surgical reconstruction.
\end{abstract}

Keywords: mesenchymal stem cells, sciatic nerve, fibrin matrix.

\section{Introduction}

Peripheral nerves damage is a frequent pathology with accounting for 13 to 23 cases per 100 people a year [1].

Even insignificant injury of the musculoskeletal system can be accompanied by the damage to peripheral nerves and cause partial or complete loss of limb function. The number of such victims is increasing annually due to increasing frequency of technogenic injuries and complex combined injuries of the musculoskeletal system. Rapid urbanization leads to increasing neurotraumatism on average by $2 \%$ per year [2]. In Ukraine,

Corresponding Author:

Volodymyr Piatykop MD, PhD, Professor,

Head of the Department of Neorosurgery.

Kharkiv National Medical University, Ukraine.

E-mail:pyatikopv@gmail.com injuries occur every year in 2500-3000 people affected, $60-75 \%$ of them are disabled.

Functional recovery has paramount importance for the rescue of limbs in the treatment of peripheral nerves injuries. [1] They can range from compression of the nerve to complete nerve transection. Trauma can affect different nerves causing respective regional paralysis. It is characterized by muscle weakness, reflexes changes, numbness, severe pain, motor dysfunction and prolonged disability.

In recent years, fundamentally new opportunities have been opened up in the reconstructive surgery of injuries and treatment of compression-ischemic lesions of nerve trunks mainly through the improvement of surgical techniques [10]. In most cases, trauma of nerves due to the specific nature of anatomical and topographic relationships is rarely isolated. Very 
often is it accompanied by damage to the blood vessels, bones and soft tissues.

Pathomorphological changes that develop after the damage of arteries and peripheral nerves are characterized by replacement of these structures with fibrous tissue and the development of tendogenic and arthrogenic contractures, delayed consolidation of bone structures as a consequence.

Despite the achievements of microsurgical techniques in the imposition of primary epineural suture or autotransplantation, the functional results are often unsatisfactory, especially if there is a significant size of the nerve defect. The effectiveness of surgical interventions on peripheral nerves depends on the type of a damage and the nature of the operational technique [5].

In connection with the foregoing, the issue of saving and adequate treatment after various injuries with the damage of peripheral nerve trunks requires development of fundamentally new methodological approaches to treatment [19].

The known surgical methods for replacing a nerve defect are mainly aimed at transplanting the nervous or any other tissue into a gap between the central and peripheral segments, as well as various artificial materials. Nerves, muscles, vessels, tubes of polymers of lactic and glycolic acids, polyphosphoether polymers are used for this. However, these techniques also have a number of drawbacks, such as development of necrosis and graft rejection. Germination of regenerating axons under these conditions is difficult and often gives complications.

Development of cellular technologies and tissue engineering methods gave new prospects for effective methods of regenerative medicine development for the restoration of peripheral nerves, such as, autotransplantation using new biopolymer materials, stem cells and tissue engineering structures $[3,14,17]$.

2. Purposes, subjects and methods:

2.1. Purpose of the work was to study the possibility of using biodegradable fibrin matrices filled with neuroinduced mesenchymal stem cells (MSC) of the bone marrow to restore the anatomical and functional integrity of the peripheral nerves in rats $[17,18]$.

\subsection{Subjects \& Methods}

The study was carried out on 40 mongrel female rats aged $4-5$ months weighing $250 \pm 50$ g., which were contained in the standard conditions of the KhNMU vivarium, in compliance with the current bioethical standards (Council Directive
86/609/EEC of 24 November 1986 on the approximation of laws, regulations and administrative provisions of the Member States regarding the protection of animals used for experimental and other scientific purposes; European Convention for the Protection of Vertebrate Animals used for Experimental and Other Scientific Purposes Strasbourg, 18.III.1986; Law of Ukraine No. 3447-IV "On the Protection of Animals from cruelty", 2006).

Sciatic nerve injury model in rats. Surgery was performed under general anesthesia (intraperitoneal administration of a mixture of solutions of xylazine - Sedazin, Biowet, Poland, $15 \mathrm{mg} \mathrm{kg}$ and ketamine - Calipsol, Gedeon Richter, Hungary, $70 \mathrm{mg} / \mathrm{kg}$ body weight). The animal was fixed on the operating table in the mid-physiological position. Observing the rules of asepsis and antiseptics, after the treatment of the operating field, a linear cut of the skin was made along the lateral surface of the left thigh in the projection of the sciatic nerve.

With the tools ("mosquito" type, surgical clamp, surgical forceps) left sciatic nerve (SN) was picked up and mobilized. At a distance $(20 \pm 1.5) \mathrm{mm}$ from the exit point of the SN from the small pelvis cavity a fragment $(7 \pm 2) \mathrm{mm}$ in length was cut by blade. After thorough hemostasis in animals of all groups, the surgical wound was closed with one row of nodular sutures using an atraumatic needle with a monofilament polyamide thread No. 3/0 (Olimp, Ukraine). Cephthriaxone ("Darnitsa", Ukraine, 20 mg/kg body weight) was used to prevent infectious complications. Solution of dexamethasone (KRKA, Slovenia, $6 \mathrm{mg} / \mathrm{kg}$ body weight) was administered intraperitoneally for anti-inflammatory and antiedematous effect. The animals were kept in a room with an increased air temperature $\left(30^{\circ} \mathrm{C}\right)$. Nerve transection and repair was done on the left limb, and the contralateral limb served as a non-transected nerve control.

\section{MSC preparation and administration}

To obtain MSC culture of rats, bone marrow was flushed from the tibia, washed twice in Hanks' solution, centrifuged at $430 \mathrm{~g}$ for 10 minutes. The cells were sowed in ratio of 50 million per culture flask (75 $\mathrm{cm}^{2}$, Nunc) and cultured in DMEM/ F12 medium (1/1) with 10\% FBS (fetal bovine serum) in a CO2 incubator. After 24 hours the culture medium with non-adherent cells to the substrate was removed, fresh culture medium was added and the remaining fibroblasts-like MSCs had been cultivated for the next 14 days, changing the medium every three days. 
After formation of the monolayer, MSC were removed from the bottom of the vials and resuspended in Hanks solution to the required concentration. All reagents, serums and media came from SIGMA-ALDRICH (USA).

Ñulture medium with 2\% fetal bovine serum and a solution of retinoic acid (10-6M) were used for neuroinduction of bone marrow MSC of rats [6].

Neuroinduced MSCs were resuspended in Hanks solution (500,000 cells/ml each) and mixed with blood plasma in a ratio of 1:2. Calcium chloride was added to the mixture to the concentration of $0.3 \%$ in solution and mixed. Then mixture was taken into a sterile silicone tube of $3 \mathrm{~mm}$ in diameter and incubated at $37{ }^{\circ} \mathrm{C}$ for 20 minutes to form a fibrin gel. After polymerization, the resulting matrix was extruded from the tube using a syringe and cut into transplants of the required size. The cell-free matrices were prepared similarly by mixing Hanks' solution with blood plasma and calcium chloride in the same proportions.

The animals were divided into 4 groups of 12 individuals each.

The sciatic nerve was cut through in the animals of the first group (E1) crossed without subsequent restoration (Fig. 1) The animals of group 2 (E2) recovered the excised fragment of the nerve trunk by epineural neuroraphy end-toend using atraumatic needle with a monofilament polyamide thread No. 9/0 (DEVTS Olimp, Ukraine) under the magnification of an operating microscope (magnification $\times 12$ ) (Fig. 2). Animals of group 3 (E3) restored the integrity of the nerve trunk with fibrin cell-free matrix (Fig. 3) In animals of group 4 (E4), the integrity of the nerve trunk was restored with fibrin matrices filled with neuroinduced mesenchymal bone marrow stem

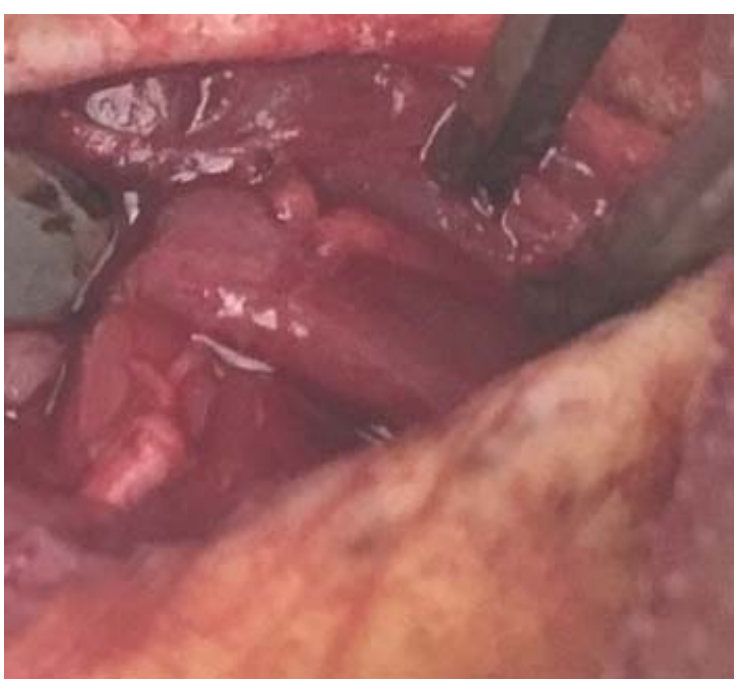

Fig. 1. Rupture without treatment

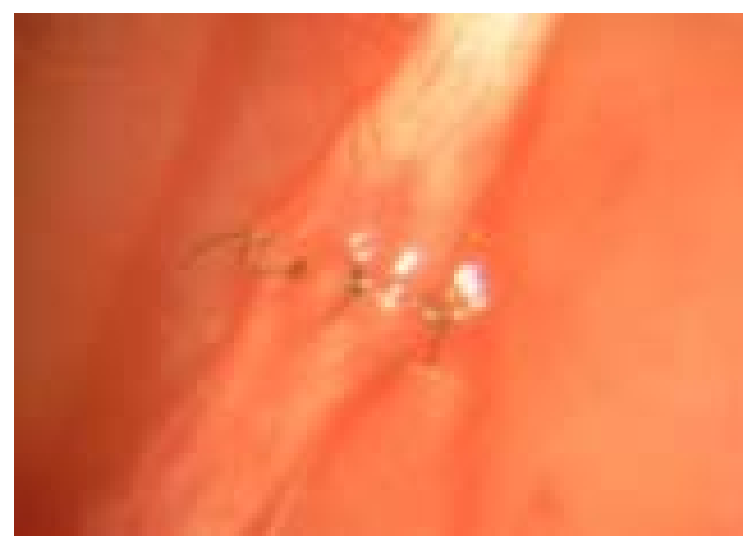

Fig. 2. Surgical Reconstruction (mag. ×10)

cells of rats (Fig. 3). In Experiments 3 and 4, the ends of the biomatrix were connected to the ends of the nerve trunk with the help of fibrin glue, which was prepared 15 minutes before application.

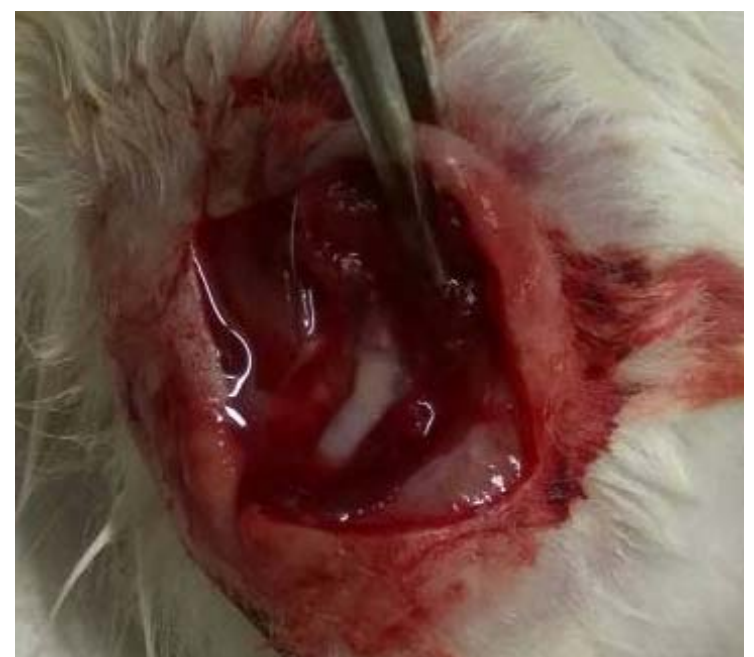

Fig. 3. Reconstruction with acellular fibrin matrix and fibrin matrix with nMSC

Assessment of neurological deficits. The degree of the sciatic nerve recovery was assessed by the results of neurological tests, which were performed 10, 20 and 30 days after the operation. To control the functional recovery we used "Walking track analysis" according to the method of Johnston et al. [15, 16] (Fig. 4) As a dye, an emerald green alcohol solution was used.

Plantar surfaces of the left (experimental, letter $\mathrm{E}$ before the indicator) and right (intact, letter $\mathrm{N}$ before the index designation) of the limbs in the same animal were measured after obtaining footprints:

PL (print length) - the distance in $\mathrm{mm}$ from the heel to the III finger

TS (toe spread) - the distance in $\mathrm{mm}$ from I to $\mathrm{V}$ finger ITS (intermediate to toe spread) - distance in $\mathrm{mm}$ from II to IV finger. 


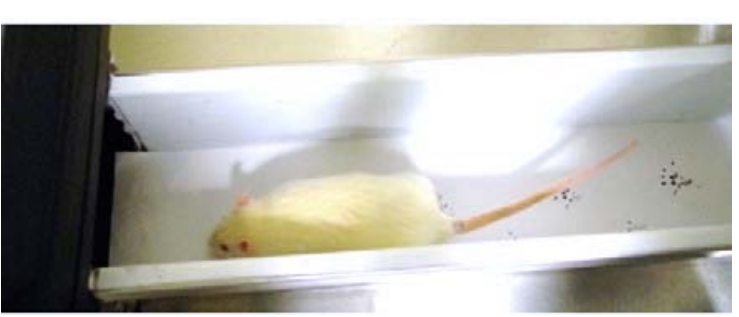

Fig. 4. "Walking track analysis" test

The data were calculated using BainMackinnon-Hunter formula and then functional index of the sciatic nerve (SFI-sciatic functional index) was evaluated.

$\mathrm{SFI}=-38.3((\mathrm{EPL}-\mathrm{NPL}) / \mathrm{NPL}))+109,5$ $(($ ETS - NTS $) / N T S))+13,3(($ EIT - NIT/NIT $))-$ 8.8 [2].

The obtained data were systematized, both the average value and the standard deviation of the index were calculated for all groups of animals.

After SFI count, the results were evaluated. Result " 0 " was the normal function of the sciatic nerve, "-100" - was a total function failure. The reliability of the differences in the SFI values obtained among animal groups was measured using the Mann-Whitney U test.

Histological methods of evaluation. The animals were removed from the experiment 30 days after the operation as a result of an thiopental anesthesia overdose. The tissues from the sciatic nerve rupture zone (E1), its operative recovery (E2), or biomatrix transplantation (E3, E4) were fixed in a $4 \%$ solution of paraformaldehyde and enclosed in paraffin blocks. The sections were stained with hematoxylin-eosin for a general cytomorphological evaluation of the tissues and with Mallory staining for the nerve fibers detection.

\section{Conflict of interests}

The authors declare that they have no competing interests.

\section{Results and discussion}

As a result of evaluation of the neurological condition of animals, it was found that a total anatomical rupture $(8-10 \mathrm{~mm})$ of SN without treatment in animals of the E1 group leads to a persistent neurologic deficit that has been persisting for 30 days of observation (SFI $=$-98) in all animals. In experimental group of animals E2 partial restoration of SN function began on the $10^{\text {th }}$ day of evaluation and increased to SFI $=$ -37 on $30^{\text {th }}$ day after operative reconstruction of nerve trunk. In E3 group of animals with a transplanted acellular fibrin matrix, the partial restoration of SN function (SFI = -64) occurred in animals after 20 days and remained stable on $30^{\text {th }}$ day after the operation. In E4 experiment, partial restoration of $\mathrm{CH}$ function was started in $80 \%$ of the animals on the $3^{\text {rd }}$ day of observation, stably increased on the $10^{\text {th }}, 20^{\text {th }}$ and $30^{\text {th }}$ days after the operation and reached values (SFI=-27), comparable with the results in the E2 group. The results of all groups are graphically displayed for comparison (Fig. 5).

Analysis of histological specimens of tissue from the trauma zone showed that in group E3 with complete anatomical rupture of SN

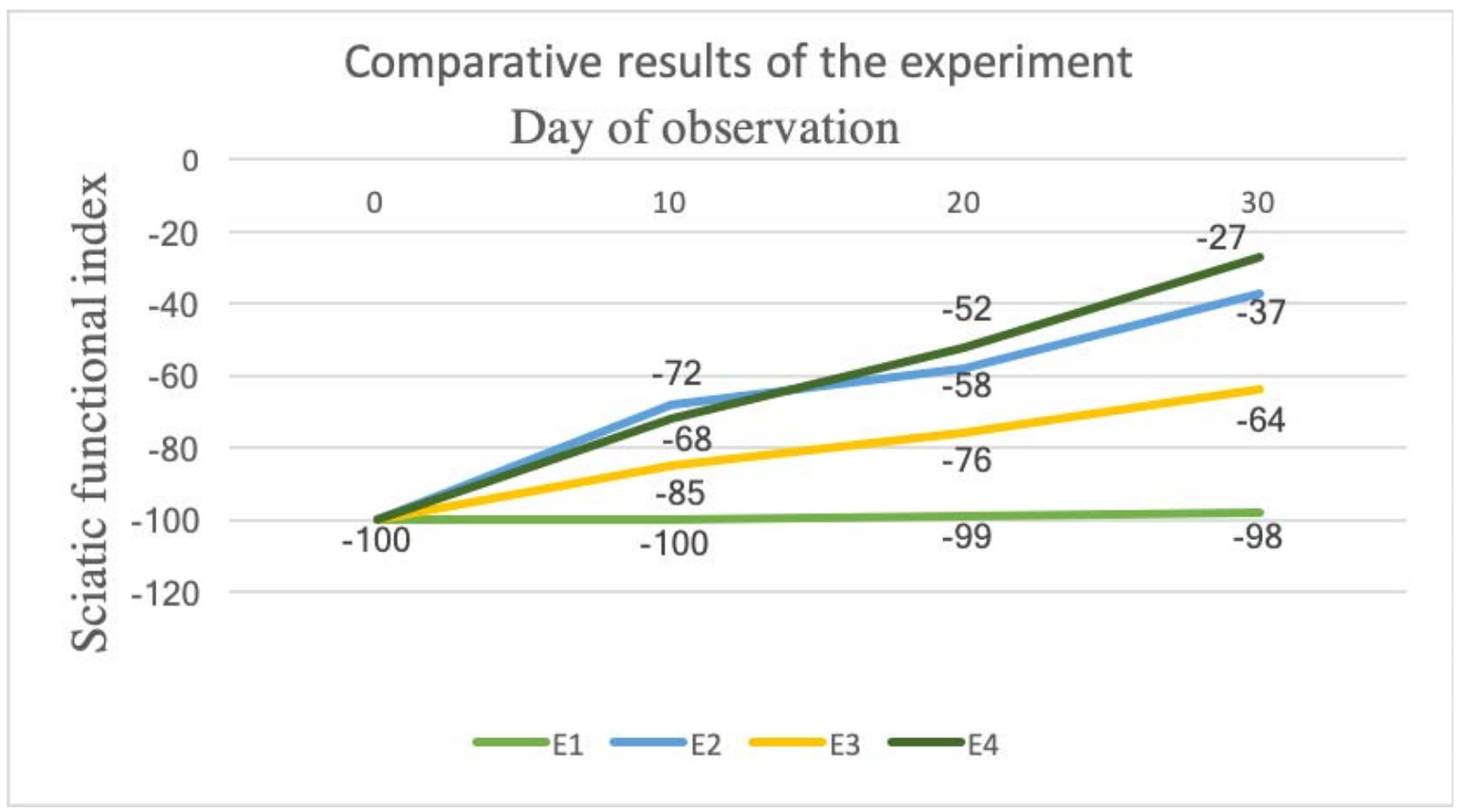

Fig. 5. The results of all groups in comparison 
spontaneous recovery of nerve fibers does not occur and connective tissue is formed at the site of SN disruption. On the tissue specimens of SN (E2) there were alternating portions of connective tissue scar with portions of nerve fibers. Apparently, it can explained the partial restoration of SN function in many animals from this group. In most animals of E3 group the formation of a large scar at the site of the transplanted fibrin matrix was observed. Only in 3 animals from this group among the fibroblasts clusters, thin nerve fibers were found. Probably, the fibrin cell-free matrix may be a substrate for the growth of nerve fibers from one end of SN to the other in some cases. Spindle-shaped and stellate cells with long processes running from one end of $\mathrm{SN}$ to the other, cells of connective tissue and thin nerve fibers except of MSC (Fig. 6) were found on

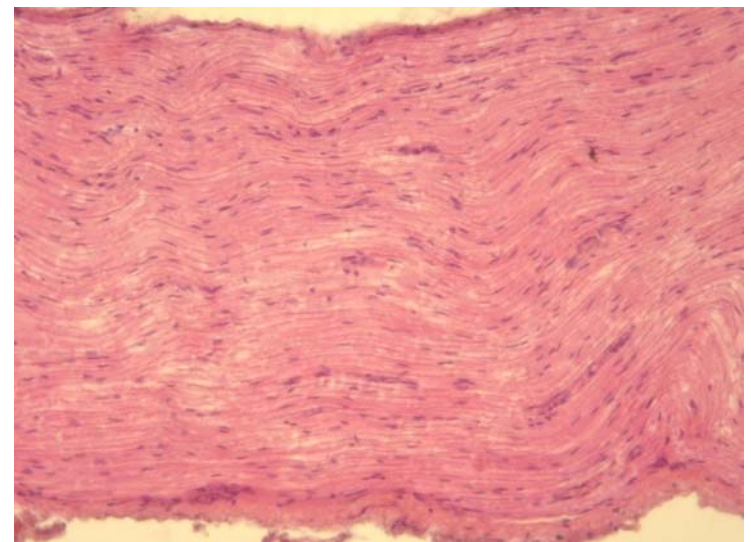

Fig. 6. Nerve tissue sample (mag. $\times 100)$

the specimens of grafts with induced MSC from the trauma zone on the 30rd day after the operation. This can explain the high efficiency of restoring the function of $\mathrm{SN}$ after transplanting the matrix with neuroinduced MSC into the zone of rupture.
Currently, the effectiveness of $\mathrm{SN}$ regeneration after transplantation of matrices based on collagen and neural stem cells polyglycolic acid and Schwann cells was shown [7]. More than 10 years ago, it was shown that bone marrow MSC can be differentiated into Schwann cells and thus support the regeneration of the peripheral nerve [8]. Therefore, the efficiency of restoring the neurological functions of the nerve with transplanted fibrin matrices with MSC in our work can be related not only with neuronal cells differentiating in the matrix and also to their transformation into Schwann cells. As methods for restoring the ends of the ruptured $\mathrm{SN}$ thin microsurgical methods of nerve fiber stitching, epinevrium and even the method of tissue welding were suggested [9]. In our work, we not only confirmed the possibility of effective treatment of SN trauma with fibrin matrix and MSC of the bone marrow, but also offered a simple method of transplanting this matrix with fibrin glue.

\section{Conclusions:}

1. The proposed model of damage to the sciatic nerve in rats by operative removal of its part (8-10 mm) leads to a persistent neurologic deficit, which persists for 30 days.

2. A method for obtaining tissue-engineering structure based on blood plasma and neuroinduced MSC of rat bone marrow for reparation of the sciatic nerve was developed.

3. This method of recovery in peripheral nerve damage utilizing MSCs is attractive, feasible, and promising. MSC therapy improved limb functional recovery in peripheral nerve damage. Research of novel approaches such as mesenchymal stem cell transplantation is expected to make a significant impact in the clinical outcome of nerve injuries.

\section{References}

1. Y Lin, Michael \& Manzano, Givenchy \& Gupta, Ranjan. (2013) Nerve Allografts and Conduits in Peripheral Nerve Repair. Hand clinics, 29, 331-348.

2. Tsymbalyuk V.I., Tretyak I.B., Gatskiy A.A (2012) The research of sciatic nerve combined plastics efficiency at it's large defect by it's functional recovery quantification in rats in experiment. Ukrainian neurosurgical journal, 3, 48-51. In Ukrainian.

3. Siemionow M., Bozkurt M., Zor F. (2010) Regeneration and repair of peripheral nerves with different biomaterials: Review. Wiley-Liss, Inc Microsurgery, 30, 574-588.

4. Torres RY, Miranda GE. (2015) Epidemiology of Traumatic Peripheral Nerve Injuries Evaluated by Electrodiagnostic Studies in a Tertiary Care Hospital Clinic. Bol Asoc Med P R, 107, 79-84.

5. Petrova D.Yu., Podgayskiy V.N., Nedzved M.K., Anischenko S.L., Mechkovskiy S.Yu., Zafranskaya M.M.. (2014) Vozmozhnost vosstanovleniya povrezhdennyih perifericheskih nervov pri transplantatsii mezenhimalnyih stvolovyih kletok. Mezhdunarodnyie obzoryi: klinicheskaya praktika i zdorove, 5, 5-14 
6. Shchegel'skaya E.A., Mikulinskii Yu.E., Revishchin A.V., Omel'chenko E.A., Kul'shin V.E., Grishchenko V.I., Pavlova G.V., Korochkin L.I. (2003) Pluripotency of bone marrow stromal cells and perspectives of their use in cell therapy. Russian Journal of Developmental Biology, 34,185-191.

7. Tsymbaliuk V. I., Petriv T. I., Medvediev V.V., Tatarchuk M. M., Draguntsova N. G., . Vasyliev R. G. (2017) Efficiency of peripheral nerve gaps restoration by different types of tissue engineering constructs according to electromyography: experimental study. Ukrainian neurosurgian Journal, 4, 60-66. In Ukrainian.

8. Ladak A., Olson J., Tredget E.E. Gordon T.. (2011) Differentiation of mesenchymal stem cells to support peripheral nerve regeneration in a rat model. Exp.Neurology, 228, 22-252.

9. Likhodiievskyi V., Korsak A., Chaikovskyi Yu, Kryvosheyeva O., Lopatkina K., Chernets V. (2015) Rats injured sciatic nerve recovery after treatment using electrosurgical instruments in welding regime. Ukrainian Scientific Medical Youth Journal, 89, 30-35.

10. Brooks DN, Weber RV, Chao JD, Rinker BD, Zoldos J, Robichaux MR, Ruggeri SB, Anderson KA, Bonatz EE, Wisotsky SM, Cho MS, Wilson C, Cooper EO, Ingari JV, Safa B, Parrett BM, Buncke GM. (2012) Processed nerve allografts for peripheral nerve reconstruction: a multicenter study of utilization and outcomes in sensory, mixed, and motor nerve reconstructions. Microsurgery, 32(1), 1-14.

11. Korus L, Ross DC, Doherty CD, Miller TA. (2016) Nerve transfers and neurotization in peripheral nerve injury, from surgery to rehabilitation. Journal of Neurology, Neurosurgery and Psychiatry, 87, 188-197.

12. Fairbairn NG, Meppelink AM, Ng-Glazier J, Randolph MA, Winograd JM. (2015) Augmenting peripheral nerve regeneration using stem cells: A review of current opinion. World J Stem Cells. Jan 26, 11-26. doi: 10.4252/wjsc.v7.i1.11. Review. PubMed PMID: 25621102; PubMed Central PMCID: PMC4300921.

13. Najafzadeh N, Esmaeilzade B, Dastan Imcheh M. (2015) Hair follicle stem cells: In vitro and in vivo neural differentiation. World Journal of Stem Cells. Jun 26; 7(5) :866-72. doi: 10.4252/wjsc.v7.i5.866. Review. PubMed PMID: 26131317; PubMed Central PMCID: PMC4478633.

14. Gatskyi O. O. Kombinovana plastyka peryferychnykh nerviv pry yikh velykykh defektakh (eksperymentalne doslidzhennia): avtoref. dys. ... kand. med. nauk : 14.01.05 / Gatskyi Oleksandr Oleksandrovych ; Nats. akad. med. nauk Ukrainy, DU "In-t neirokhirurhii im. A. P. Romodanova NAMN Ukrainy". - Kyiv. - 2015. - 23 s.

15. Tsymbaliuk VI, Petriv TI, Molotkovets VY, Vasyliev RG, Tatarchuk MM, Burkush II. (2017) Development of walking track device for functional recovery analysis after experimental sciatic nerve injury. World of medicine and biology, 3, 157-160.

16. L. Sarikcioglu, B. M. Demirel, A. Utuk (2009) Walking track analysis: an assessment method for functional recovery after sciatic nerve injury in the rat. Morphologia, 68, 1-7.

17. Pyatikop V.A., Karamyishev V.D., Shevereva V.M., Dvortsevoy V.K.. (2006) Gistologicheskiy analiz izmeneniy tkaney golovnogo mozga krys s eksperimentalnyim parkinsonizmom do i posle transplantatsii kriokonservirovannyih embrionalnyih nervnyih kletok. Problemy kriobiologii, 16(2): 211-6. 5.

18. Pyatikop V.A., Schegelskaya E.A., Mikulinskiy Yu.E. (2005) Vosstanovlenie strukturnofunktsionalnyih parametrov u kryis s kriogennoy travmoy golovnogo mozga posle transplantatsii kletok stromyi kostnogo mozga, indutsirovannyih v neyroblastyi. Problemy kriobiologii, 15(3): 449-51.

19. Vladimir Pyatikop, Mohammad Ahmad Msallam Jr, Elena Shchegelskaya, Igor Kutovoy, Galina Gubina-Vakulik (2014) Migration features of labeled bone marrow mesenchymal stem cells in rats with modeled Parkinson-like syndrome. Ukrainian neurosurgical journal, 3, 42-48

Received: 04-Jun-2019 Accepted: 16-Sep-2019 